Article

\title{
Influence of Canopy Cover and Meteorological Factors on the Abundance of Bark and Ambrosia Beetles (Coleoptera: Curculionidae) in Avocado Orchards Affected by Laurel Wilt
}

\author{
Octavio Menocal $^{1, *}$, Paul E. Kendra ${ }^{2} \mathbb{D}$, Armando Padilla ${ }^{1}$, Pollyana C. Chagas ${ }^{1,3}$, Edvan A. Chagas ${ }^{1,4} \mathbb{D}^{\mathbb{1}}$, \\ Jonathan H. Crane ${ }^{1}$ (D) and Daniel Carrillo ${ }^{1}$ (D)
}

Citation: Menocal, O.; Kendra, P.E.; Padilla, A.; Chagas, P.C.; Chagas,

E.A.; Crane, J.H.; Carrillo, D.

Influence of Canopy Cover and Meteorological Factors on the Abundance of Bark and Ambrosia Beetles (Coleoptera: Curculionidae) in Avocado Orchards Affected by Laurel Wilt. Agronomy 2022, 12, 547. https://doi.org/10.3390/ agronomy12030547

Academic Editor: Kris Wyckhuys

Received: 28 January 2022

Accepted: 17 February 2022

Published: 22 February 2022

Publisher's Note: MDPI stays neutral with regard to jurisdictional claims in published maps and institutional affiliations.

Copyright: (C) 2022 by the authors. Licensee MDPI, Basel, Switzerland. This article is an open access article distributed under the terms and conditions of the Creative Commons Attribution (CC BY) license (https:// creativecommons.org/licenses/by/ $4.0 /)$.
1 Tropical Research and Education Center, University of Florida, Homestead, FL 33031, USA; apadilla1@ufl.edu (A.P.); pollyana.chagas@ufrr.br (P.C.C.); edvan.chagas@embrapa.br (E.A.C.); jhcr@ufl.edu (J.H.C.); dancar@ufl.edu (D.C.)

2 United States Department of Agriculture, Agricultural Research Service, Subtropical Horticulture Research Station, USDA-ARS, 13601 Old Cutler Rd., Miami, FL 33158, USA; paul.kendra@usda.gov

3 Departamento de Fitotecnia, Campus Cauamé, Universidade Federal de Roraima, BR 174, Monte Cristo, Boa Vista CEP 69304-940, RR, Brazil

4 Empresa Brasileira de Pesquisa Agropecuária (Embrapa), Rod. BR 174, Km 08, Distrito Industrial, Boa Vista CEP 69301-970, RR, Brazil

* Correspondence: omenocal18@ufl.edu

\begin{abstract}
In the last decade in South Florida, approximately 200,000 avocado trees have succumbed to laurel wilt (LW), a fungal disease vectored by ambrosia beetles. Sanitation (e.g., pruning, stumping, and removal of LW-affected trees) and replanting with young trees are cultural practices currently used by avocado growers to reduce the incidence of LW. Surveillance in these managed orchards suggests a decline in ambrosia beetle abundance, and previous research determined that female flight activity is influenced by light intensity. Therefore, we investigated the effect of three canopy covers (i.e., full canopy, topworked, and new planting) on ambrosia beetle abundance. A total of 28,184 individuals, representing 15 species within Scolytinae and Platypodinae, were captured passively in three LW-affected avocado orchards over a one-year period. Full canopy cover exhibited the highest number of beetles and the lowest light intensity. The opposite was found for topworked and new planting covers. Additionally, we documented the effect of meteorological factors on the flight dispersal of five species known to vector the LW pathogen. The flight activity of Xylosandrus crassiusculus and Xyleborinus saxesenii was highly influenced by abiotic factors $\left(R^{2}>0.50\right)$, especially solar radiation, whereas the flight of Xyleborus affinis, Xyleborus volvulus, and Xyleborus bispinatus was only partially explained by climatic variables $\left(0.20<R^{2}<0.30\right)$. Our results indicate that reducing canopy cover, thereby increasing light intensity, suppresses ambrosia beetle abundance, especially for species associated with the LW pathogen. Abiotic factors play a critical role in the dispersal of invasive species (X. crassiusculus and X. saxesenii), but their effect is less pronounced on native species (X. affinis, X. volvulus, and X. bispinatus). Canopy management alters the microclimatic conditions in avocado orchards, affecting ambrosia beetle abundance and flight activity.
\end{abstract}

Keywords: abiotic factors; canopy management; canopy openness; decision tree analysis; microclimate; Persea americana; Raffaelea lauricola; Scolytinae; seasonality; weather

\section{Introduction}

Avocado (Persea americana Mill.) is the most important commodity from the Lauraceae family. Avocado production in the Americas has increased significantly in the past two decades. Mexico is the world's largest producer of avocado, with more than two million tons, followed by the Dominican Republic $(661,000)$, Peru $(535,000)$, and Colombia $(535,000)$ [1]. In the United States, avocado production in Florida has been impacted by a new lethal disease known as laurel wilt (LW). This is a fungal disease transmitted by 
ambrosia beetles (Coleoptera: Curculionidae: Scolytinae: Xyleborini) that represents a potential threat to avocado industries in California, Mexico, and the rest of Latin America.

Raffaelea lauricola T. C. Harr., Fraedrich \& Aghayeva (Ophiostomatales: Ophiostomataceae), is the causative agent of LW, a vascular disease responsible for the mortality of ca. 200,000 avocado trees in South Florida. Although its primary vector, Xyleborus glabratus Eichhoff, is rarely detected in avocado systems [2-8], other ambrosia beetle species have acquired this symbiont and now function as alternative vectors [9-11].

Mature avocado orchards (50+ year-old trees) with close spacings and/or overgrown canopy cover have been severely affected by LW over the past decade. Avocado growers have employed sanitation practices such as pruning (e.g., hedging and topping), stumping (topworking), hat-racking, removing LW-affected trees, and replanting with young trees. These practices have sometimes resulted in a downward trend in tree infection and subsequent tree regrowth. Consequently, many severely affected orchards appear rejuvenated and have resumed production even though the mechanisms involved in the decline of LW incidence in these orchards are poorly understood. Pest monitoring in these orchards suggests there is a decrease in ambrosia beetle activity in stumped, hat-racked, and/or topworked sections in the orchards and areas replanted with young trees. Changes in canopy cover may alter the microclimate below the canopy by affecting the amount of light [12], temperature, and wind speed [13], which can also affect ambrosia beetle dynamics. Therefore, altering the canopy cover of avocado orchards may affect ambrosia beetle abundance, species composition, and flight activity.

In general, bark and ambrosia beetles have a defined flight periodicity [3,14-17], and females only engage in flight when suitable conditions are met [18]. In a previous study, ambrosia beetle flight activity in avocado orchards was influenced by light intensity, wind speed, and temperature [5]. A reduction in the flight of Xylosandrus crassiusculus (Motschulsky) during periods of heavy rainfall was reported [19]; however, high ambrosia beetle activity during rainy seasons has also been reported [20]. Dispersal flights of other scolytine species, such as Ips typographus L. and Pityophthorus juglandis Blackman, were reported to be influenced by solar radiation and relative humidity, respectively [21-23]. These results suggest that multiple abiotic factors influence the flight behavior of Scolytinae.

Understanding how different canopy covers affect abiotic factors within the canopy and the abundance and flight activity of LW vectors in avocado orchards could be critical for improving cultural practices by avocado growers. Therefore, the objectives of the current study were to (1) determine if canopy coverage affects the abundance and species composition of ambrosia beetle communities in LW-affected avocado orchards in Florida, (2) relate the abundance of LW vectors to the light intensity beneath each canopy cover, and (3) investigate the effect of meteorological factors on the abundance of dispersing ambrosia beetle females, especially those associated with the LW pathogen.

\section{Materials and Methods}

\subsection{Study Area}

Three commercial avocado orchards affected by LW, each with large areas with different canopy coverage, were used to study the effect of canopy cover and meteorological conditions on ambrosia beetle abundance from March 2018 to March 2019 in Homestead, FL (Miami-Dade County). The first orchard $\left(25^{\circ} 26^{\prime} 17^{\prime \prime} \mathrm{N} ; 80^{\circ} 31^{\prime} 40^{\prime \prime} \mathrm{W}\right.$ ) was about 15 years old and had approximately 35 ha of avocado trees of six cultivars ('Beta', 'Donnie', 'Seedling\#2', 'Seedling\#12', 'Seedling\#13', and 'Seedling\#14'). Mature trees were spaced $5.18 \mathrm{~m} \times 8.23 \mathrm{~m}$ and young trees, $3.20 \mathrm{~m} \times 8.84 \mathrm{~m}$. Trees were approximately $3.5 \mathrm{~m}$ in height and were planted on a 1-m-high bed of native soil to avoid flooding after heavy rainfall events. LW-affected avocado trees were immediately removed to prevent build-up of ambrosia beetle populations. The second orchard $\left(25^{\circ} 32^{\prime} 43^{\prime \prime} \mathrm{N} ; 80^{\circ} 26^{\prime} 54^{\prime \prime} \mathrm{W}\right)$ was over 50 years old and had approximately 15 ha of avocado trees with eight cultivars ('Dupuis', 'Miguel', 'Dupuis \#3', 'Lula', 'Manuel', 'Donnie', 'Booth \#7', and 'Booth \#8'). The third orchard $\left(25^{\circ} 36^{\prime} 16^{\prime \prime} \mathrm{N} ; 80^{\circ} 28^{\prime} 07^{\prime \prime} \mathrm{W}\right)$ was also over 50 years old and had approximately 35 ha of 
avocado trees, with nine cultivars ('Beta', 'Nadir', 'Nesbitt', 'Tower \#2', 'Donnie', 'Harder', 'Miguel', 'Dupuis', and 'Bernecker'). Orchards 2 and 3 had similar tree spacing; mature trees were separated by $5.50 \mathrm{~m} \times 7.32 \mathrm{~m}$ and young trees, by $5.50 \mathrm{~m} \times 6.55 \mathrm{~m}$. Mature trees were more than $6 \mathrm{~m}$ tall with loss of the lower lateral scaffold limbs due to shading by the upper canopy. Orchards 2 and 3 had several standing LW-affected trees and exhibited widespread ambrosia beetle infestations. All three orchards had a north-south row orientation and were selected because each had large areas with different canopy coverages under the same pest management strategy.

\subsection{Canopy Cover and Sampling of Ambrosia Beetles in Avocado Orchards}

Ambrosia beetle composition and abundance were evaluated in three sections that differed in canopy cover within each orchard: (1) newly planted trees, younger than two years old; (2) topworked trees, recently stumped or pruned within the last three years; and (3) full canopy trees, either infrequently or not pruned (Figure 1). In each section (ca. 0.40 ha), five black 8-unit Lindgren funnel traps (Item \#2853; BioQuip Products, Inc., Rancho Dominguez, CA, USA) specifically designed to monitor wood-boring beetles were located between trees within rows separated by at least $6 \mathrm{~m}$ within rows and $8 \mathrm{~m}$ between rows, placed $\sim 1.5 \mathrm{~m}$ above ground. Traps were placed at least $10 \mathrm{~m}$ apart from LW-symptomatic trees. No lures were used to avoid alteration of the natural flight pattern of ambrosia beetles and assess passive baseline captures. Collection cups were filled with 200 mL of propylene glycol (Super Tech RV \& Marine Antifreeze (Item \# 563036502); Walmart Inc., Bentonville, AR, USA) and attached at the bottom of the traps to maintain and preserve the specimens collected. Traps were serviced biweekly to collect the specimens and replace the propylene glycol. All samples were stored at $-20{ }^{\circ} \mathrm{C}$ at the Tropical Fruit Entomology Laboratory (UF/IFAS-Tropical Research and Education Center, Homestead, FL, USA). All Scolytinae and Platypodinae specimens, except for Hypothenemus spp., were identified to the species level according to Rabaglia et al. [24], Atkinson et al. [25], and Gomez et al. [26] under a dissecting stereomicroscope.
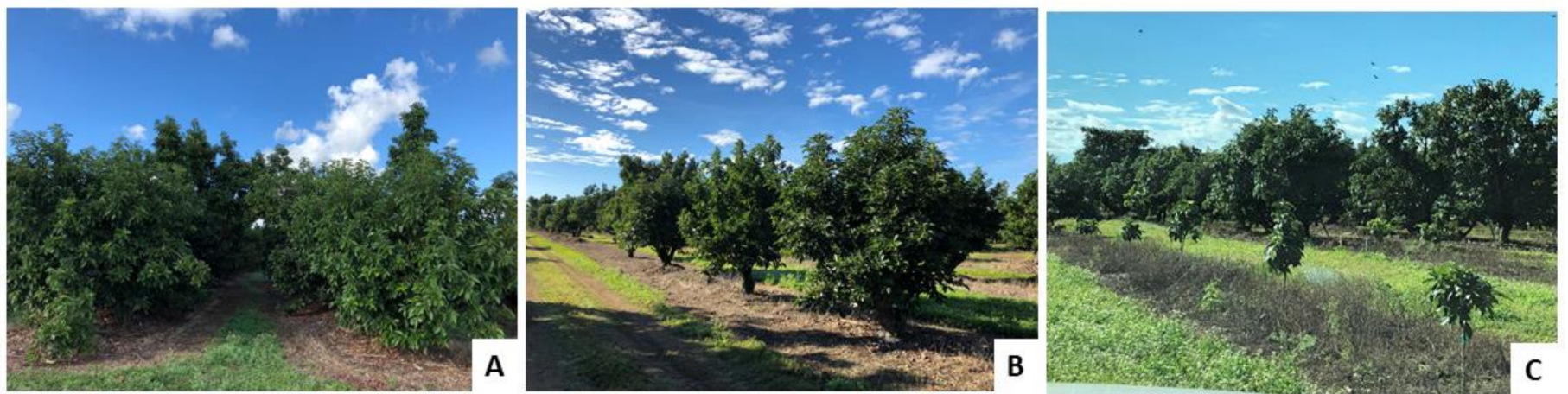

Figure 1. Commercial avocado orchards exhibiting three canopy covers. (A) Full canopy, (B) Topworked, (C) New planting. Photo credit: J. H. Crane.

\subsection{Light Intensity under Canopy Covers}

To investigate the relationship between light intensity and the abundance of LWvectors, HOBO Pendant ${ }^{\circledR}$ Light 64K Data Loggers (Part \# UA-002-64; ONSET Computer Corporation, Bourne, MA, USA) were placed on top of Lindgren traps to record light intensity levels below each of the three canopy covers in the three orchards from March 2018 to June 2018. (Beetles were collected and identified as described above).

\subsection{Meteorological Data}

Meteorological variables, consisting of maximum, average, and minimum air temperature $\left({ }^{\circ} \mathrm{C}\right)$; maximum, average, and minimum precipitation $(\mathrm{mm})$; maximum, average, and minimum relative humidity (\%); and maximum, average, and minimum solar ra- 
diation $\left(\mathrm{W} / \mathrm{m}^{2}\right)$ were obtained from the Florida Automated Weather Network (FAWN) (https: / / fawn.ifas.ufl.edu/ accessed on 28 May 2020). Data were collected at the Tropical Research and Education Center FAWN weather station, located $\sim 8.5 \mathrm{~km}$ northeast of the first orchard, $\sim 6.5 \mathrm{~km}$ southwest of the second orchard, and $\sim 11.2 \mathrm{~km}$ southwest of the third orchard. The FAWN provides daily averages for each weather variable. From this data set, biweekly weather variables were generated to match the period in which traps were serviced.

\subsection{Statistical Analysis}

Data were analyzed using SAS v. 9.4 (PROC MIXED SAS/Stat 15.1, SAS Institute, Cary, NC, USA). The effects of the canopy cover, orchard, and their interaction were evaluated for the total number of beetles (i.e., all species combined) and the number of each species using two-way analysis of variance (ANOVA). Light intensity levels did not differ significantly among avocado orchards; therefore, data were pooled and compared only among canopy covers. Significant differences were then followed by mean separation with Tukey's HSD test at a critical level of $\alpha=0.05$. The numbers of X. crassiusculus, X. affinis, X. volvulus, $X$. bispinatus, and X. saxesenii were correlated with light intensity using the Spearman's rank correlation coefficient. Field captures were expressed as beetles/trap/biweekly. Data not normally distributed were square root $(x+0.5)$ - transformed before the analyses to meet the normality assumptions. Results are presented as the mean \pm standard error of the mean (SEM) unless otherwise indicated.

\subsection{Decision Tree (DT) Analysis}

The effect of meteorological factors on ambrosia beetle abundance was determined through a decision tree analysis (Partition Modeling Option) using JMP Pro.14.0 software (SAS Institute, Cary, NC, USA). Briefly, DT analysis is a non-parametric regression method (i.e., alternative to multiple regression analysis) that is based on binary recursive partitioning of the data [27-30]. The decision tree schematics generated in this study were built using the count captures of beetles/trap/biweekly $(N=81)$ as response variable(s) and the weather data $(N=12)$ as explanatory variables. Then, the decision tree algorithm selected the most statistically significant explanatory variable(s) for estimating beetle abundance. In this case, the data (parent node) were divided into smaller subsets (child nodes) according to the strength of the relationship. Once the data were split, the two resulting subsets became the new parent nodes, and the process continued until all observations were classified. The "K Fold Crossvalidation" option was used to constrain optimization using five training sets ( 5 "folds") within the cohort. This stopping rule ceases the splitting when improvement of the $R^{2}$ is minimal. In other words, a model is selected when there is no longer a significant improvement in the $R^{2}$ after adding an extra independent variable. This option prevents overfitting, optimizes misclassification error, and limits tree size (i.e., number of splits).

\section{Results}

3.1. Effect of Canopy Cover on Ambrosia Beetle Abundance and Composition in LW-Affected Avocado Orchards

A total of 28,184 bark and ambrosia beetles, representing 15 species, were captured passively in three avocado orchards over a one-year period (Table 1). Xyleborinus saxesenii (Ratzeburg) (43.69\%) made up the largest percentage of captures, followed by Hypothenemus spp. (28.81\%), X. crassiusculus (11.75\%), Xyleborus volvulus (Fabricius) (5.90\%), Xyleborus affinis Eichhoff (2.65\%), Xyleborinus andrewesi (Blandford) (1.80\%), Xyleborus bispinatus Eichhoff (1.15\%), Ambrosiodmus lecontei Hopkins (1.15\%), Euplatypus paralellus (Fabricius) (0.67\%), Theoborus ricini (Eggers) (0.60\%), Premnobius cavipennis Eichhoff (0.56\%), Euwallacea perbrevis (Schedl) (0.49\%), Xyleborus ferrugineus (Fabricius) (0.46\%), Xyleborinus gracilis (Eichhoff) (0.19\%), and Ambrosiodmus minor (Stebbing) (0.13\%). All 15 species were present in each of the three orchards (Table 1). Species previously reported in association with 
the LW pathogen (i.e., X. crassiusculus, X. affinis, X. volvulus, X. bispinatus, and X. saxesenii) were more abundant in orchards 2 and 3 (Table 1). Species not known to interact with the LW pathogen in avocado (i.e., A. lecontei, A. minor, E. perbrevis, P. cavipennis, T. ricini, X. andrewesi, X. gracilis, Hypothenemus spp., and E. parallelus) were more abundant in orchard 1.

Table 1. Captures of Scolytinae and Platypodinae (Coleoptera: Curculionidae) species in unbaited Lindgren funnel traps deployed in three -avocado orchards affected by laurel wilt (Miami-Dade Co. FL).

\begin{tabular}{|c|c|c|c|}
\hline Species & Orchard 1 & Orchard 2 & Orchard 3 \\
\hline \multicolumn{4}{|l|}{ Subfamily Scolytinae } \\
\hline \multicolumn{4}{|l|}{ Tribe Xyleborini } \\
\hline Ambrosiodmus lecontei Hopkins $\S$ & 135 & 91 & 99 \\
\hline Ambrosiodmus minor (Stebbing) & 24 & 11 & 1 \\
\hline Euwallacea perbrevis (Schedl) & 54 & 50 & 34 \\
\hline Premnobius cavipennis Eichhoff & 96 & 23 & 38 \\
\hline Theoborus ricini (Eggers) & 136 & 24 & 10 \\
\hline Xyleborinus andrewesii (Blandford) $\S$ & 354 & 131 & 22 \\
\hline Xyleborinus gracilis (Eichhoff) $\S$ & 37 & 9 & 7 \\
\hline Xyleborinus saxesenii (Ratzeburg) & 1586 & 6802 & 3925 \\
\hline Xyleborus affinis Eichhoff $\S$ & 189 & 317 & 240 \\
\hline Xyleborus bispinatus Eichhoff $\S$ & 53 & 135 & 137 \\
\hline Xyleborus ferrugineus (Fabricius) $\S$ & 44 & 40 & 46 \\
\hline Xyleborus volvulus (Fabricius) $\S$ & 419 & 687 & 558 \\
\hline Xylosandrus crassiusculus (Motschulsky) $\S$ & 141 & 1278 & 1894 \\
\hline \multicolumn{4}{|l|}{ Tribe Cryphalini } \\
\hline Hypothenemus spp. & 5452 & 726 & 1941 \\
\hline \multicolumn{4}{|l|}{ Subfamily Platypodinae } \\
\hline Euplatypus parallelus (Fabricius) & 94 & 60 & 34 \\
\hline Total $\varepsilon$ & 8814 & 10384 & 8986 \\
\hline
\end{tabular}

$\S_{\text {Ambrosia beetle species from which Raffaelea lauricola, causal agent of laurel wilt, has been recovered }[9,10]}$ ${ }^{\varepsilon}$ Total number of Scolytinae and Platypodinae species captured in three avocado orchards during a one-year period (March 2018-March 2019).

There was a significant interaction between canopy cover and avocado orchard in terms of the total number of beetle captures (i.e., all species combined) $(F=2.50 ; d f=4,972$; $p=0.0412$ ) (Figure 2). In orchard 1, traps under full canopy cover captured significantly more beetles than traps in topworked and new planting covers. In orchard 2, no significant difference was found between total beetle captures amongst the three covers. In orchard 3, total beetle captures under full canopy and topworked covers were similar and significantly greater than those under new planting cover.

When separate ANOVAs were conducted by species, captures of X. crassiusculus were significantly affected by canopy cover and orchard $(F=3.01 ; d f=4,1206 ; p=0.0175)$. In contrast, captures of $X$. affinis $(F=4.67 ; d f=2,603 ; p=0.0097), X$. volvulus $(F=15.92 ; d f=2$, 928; $p<0.001)$, $X$. bispinatus $(F=3.07 ; d f=2,543 ; p=0.0473), X$. saxesenii $(F=3.8042 ; d f=2$, $640 ; p=0.0225)$, and $X$. ferrugineus $(F=4.98 ; d f=2,1204 ; p=0.0070)$ were only affected by canopy cover.

Captures of X. crassiusculus in traps located under full canopy cover in orchards 2 and 3 were significantly greater than those in topworked and new planting areas. However, captures amongst the three canopy covers in orchard 1 did not differ statistically (Figure 2). Xylosandrus crassiusculus flight peaked between March and late July in orchards 2 and 3. No flight peak was observed in orchard 1 (Figure S1). Captures of X. affinis and X. volvulus were higher in traps located under full canopy cover than traps under topworked and new planting canopy covers across all three orchards (Figure 3A,B, respectively). Xyleborus affinis showed two dispersal peaks: one in April to late June, consistent among the three orchards, and one between November and December only in orchard 2 (Figure S2). Xyleborus volvulus showed a more irregular flight pattern across the year in the three orchards (Figure S3). Captures of $X$. bispinatus were equivalent between full and topworked canopy but higher 
than those under new planting cover (Figure 3C). Xyleborus bispinatus flight peaked between April to late June in orchard 2 and between November and December in orchard 3. No flight peak was observed in orchard 1 (Figure S4). Captures of X. saxesenii under topworked areas were significantly higher than those in new plantings, whereas captures under full canopy were similar to those under topworked and new planting covers (Figure 3D). Xyleborinus saxesenii initiated flight in early March and continued until late July. The seasonal flight pattern was consistent in orchards 2 and 3 (Figure S5). Finally, captures of X. ferrugineus were significantly higher in newly planted areas than in full canopy and topworked canopy cover areas.

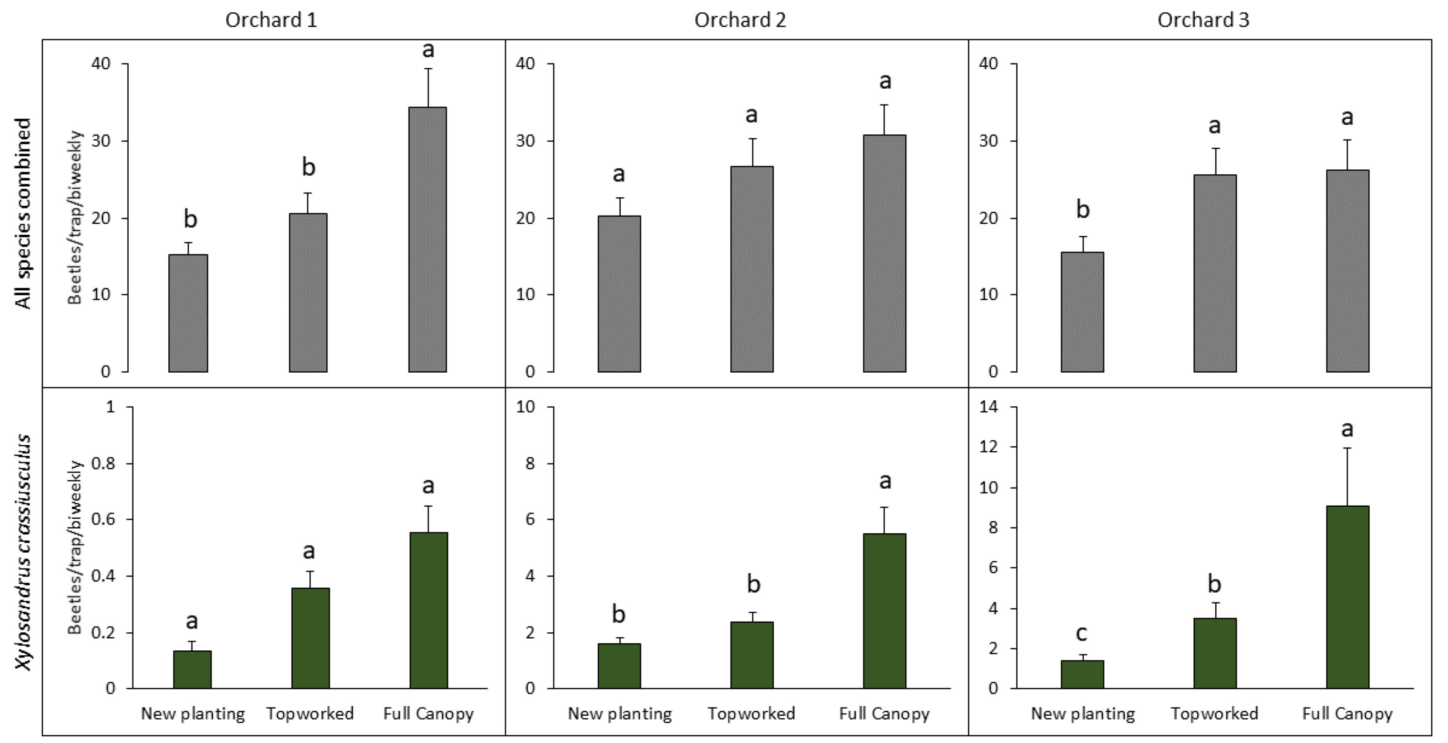

Figure 2. Average ( \pm SEM) captures of all ambrosia beetle species combined (top row) and Xylosandrus crassiusculus (bottom row) in three commercial avocado orchards with laurel wilt over a one-year period. Error bars with the same letters are not significantly different (Tukey HSD; $\alpha=0.05$ ). (Note different scales on the y-axis).

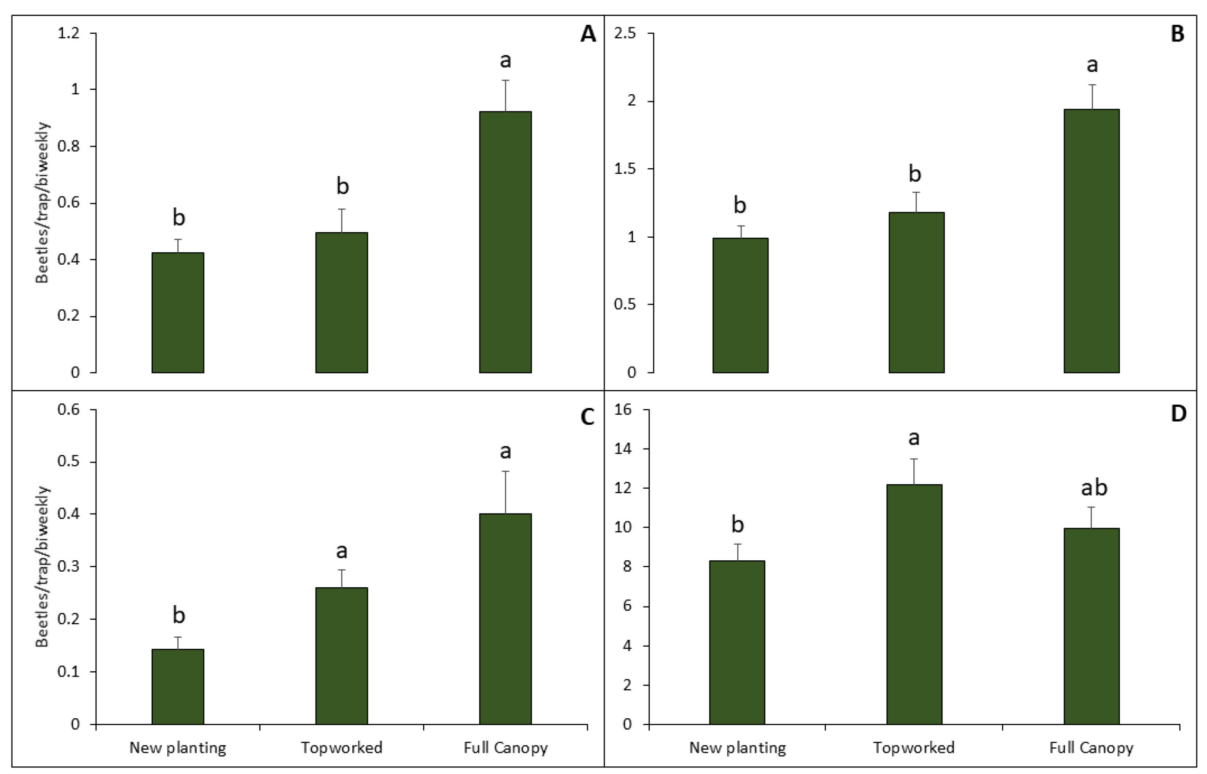

Figure 3. Average ( \pm SEM) captures of LW vectors in three commercial avocado orchards (pooled) with laurel wilt over a one-year period. (A) Xyleborus affinis, (B) Xyleborus volvulus, (C) Xyleborus bispinatus, and (D) Xyleborinus saxesenii. Error bars with the same letters are not significantly different (Tukey HSD; $\alpha=0.05)$. (Note different scales on the y-axis). 
The remaining beetle species such as $X$. andrewesi $(F=5.63 ; d f=2,1206 ; p=0.0002)$, A. lecontei $(F=3.64 ; d f=2,1206 ; p=0.0059)$, $T$. ricini $(F=7.86 ; d f=2,1206 ; p<0.0001)$, Hypothenemus spp. $(F=3.74 ; d f=2,730 ; p=0.0051)$, E. parallelus $(F=7.81 ; d f=4,1206$; $p<0.0001)$, and E. perbrevis $(F=6.59 ; d f=4,1206 ; p<0.0001)$ were significantly affected by canopy cover and avocado orchard. In contrast, captures of $P$. cavipennis $(F=3.37$; $d f=2,1206 ; p=0.0346$ ) were only affected by canopy cover. No significant differences were found in the number of captures of $X$. gracilis $(F=0.71 ; d f=2,1206 ; p=0.4916)$ and $A$. minor $(F=0.63 ; d f=2,1206 ; p=0.5338)$ among the canopy covers.

Captures of $X$. andrewesi were significantly higher in traps under full canopy than those under topworked and new planting covers in orchards 1 and 2 . However, no differences in $X$. andrewesi captures were found among canopy covers in orchard 3. Captures of $A$. lecontei were equivalent between topworked and new planting covers but were significantly lower than those under full canopy cover in orchards 1 and 3. Captures of A. lecontei were similar among the three canopy covers in orchard 2. Captures of T. ricini, Hypothenemus spp., E. parallelus, and E. perbrevis were significantly higher under full canopy than those in topworked and new planting covers for orchard 1, whereas no significant differences were observed in their capture numbers among the three canopy covers in orchards 2 and 3. Captures of $P$. cavipennis were equivalent between the full canopy and topworked areas but were higher than those under new planting covers.

\subsection{Effect of Light Intensity under Canopy Cover on Abundance of LW Vectors}

Light intensity was significantly affected by canopy cover $(F=15.0735 ; d f=2,299 ; p=0.0005)$. Light intensity under full canopy cover exhibited the lowest value $(31,822.15 \pm 859.38$ lux $)$ compared to topworked $(61,666.64 \pm 1630.96 \mathrm{lux})$ and new planting $(78,715.28 \pm 1591.39 \mathrm{lux})$ areas. Captures of X. crassiusculus $\left(r_{s}=-0.7312 ; p=0.0002\right)$, X. affinis $\left(r_{s}=-0.5459\right.$; $p=0.0105)$, and $X$. volvulus $\left(r_{s}=-0.5832 ; p=0.0055\right)$ were significant negatively correlated with light intensity but not the captures of $X$. bispinatus $\left(r_{s}=-0.2723 ; p=0.2324\right)$ and $X$. saxesenii $\left(r_{s}=-0.4169 ; p=0.0601\right)$. Figure 4 displays the relationship between beetle abundance and light intensity. Xylosandrus crassiusculus (Figure 4A), X. affinis (Figure 4B), and $X$. volvulus (Figure $4 \mathrm{C}$ ) preferred low levels of light intensity whereas $X$. bispinatus (Figure 4D) and X. saxesenii (Figure 4E) did not differ between levels of light intensity.
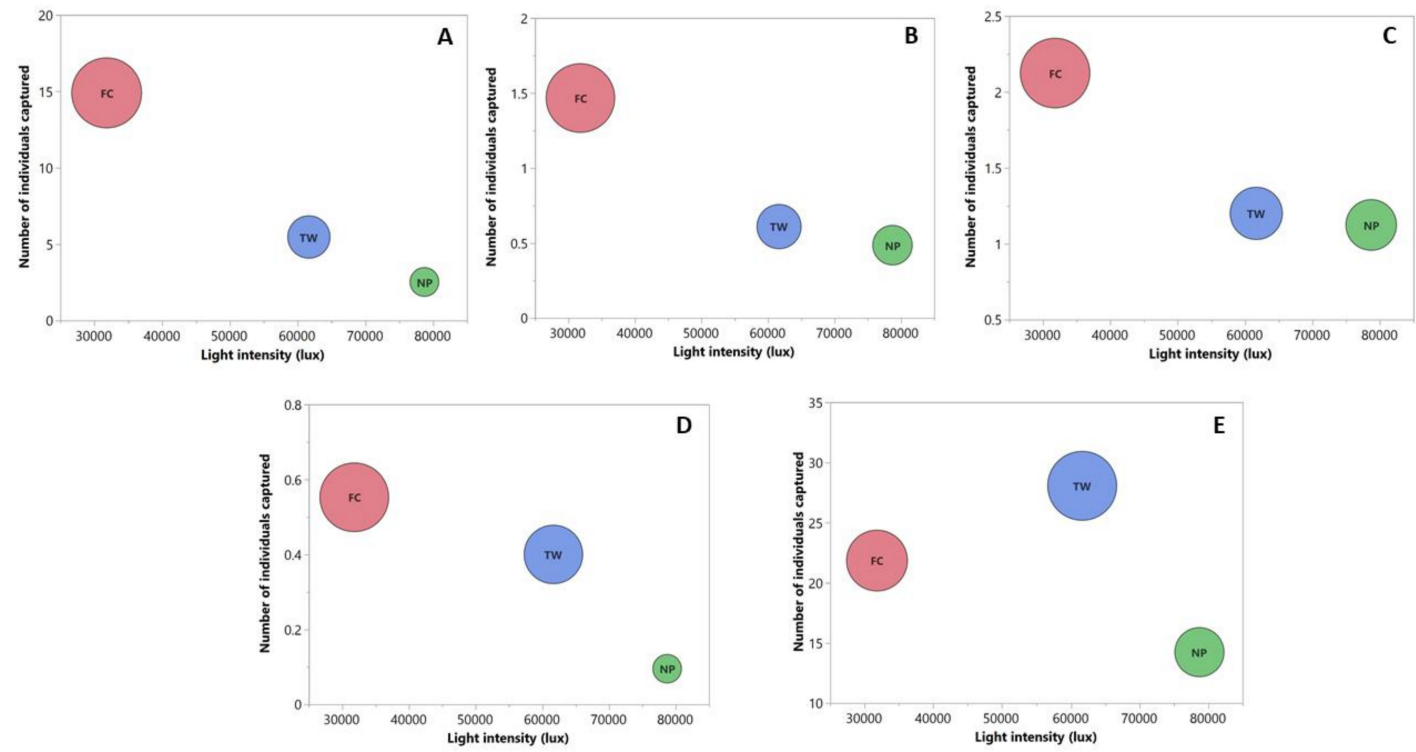

Figure 4. Relationship between LW vector abundance and light intensity levels in LW-affected avocado orchards during a four-month period (March 2018-June 2018). Bubbles of different sizes represent the abundance of beetles. (A) Xylosandrus crassiusculus, (B) Xyleborus affinis, (C) Xyleborus volvulus, (D) Xyleborus bispinatus, and (E) Xyleborinus saxesenii. (Note different scales on the y-axis). $\mathrm{FC}=$ Full canopy; TW = Topworked; NP = New planting. 


\subsection{Effect of Meteorological Factors on Ambrosia Beetle Flight Activity-Decision Tree Analyses}

Five ambrosia beetle species typically associated with the LW pathogen in Florida avocado orchards were used to build decision tree analyses using abiotic factors as explanatory variables to predict their abundance. The decision tree $\left(R^{2}=0.733\right.$; $\log$ Worth $=6.8264$; $N=81$ ) generated for $X$. saxesenii contained maximum solar radiation as the first split (i.e., most influential variable), minimum temperature as the second split, and maximum precipitation as the third split. Critical values are presented in Figure 5. The decision tree for X. crassiusculus $\left(R^{2}=0.563\right.$; $\log$ Worth $\left.=9.6703 ; N=81\right)$ included maximum solar radiation and mean and minimum temperatures as secondary splits (Figure 6). The decision tree of $X$. affinis $\left(R^{2}=0.296\right.$; $\log$ Worth $\left.=1.9110 ; N=81\right)$ indicated that the abundance of this species was influenced by maximum solar radiation, minimum solar radiation, and maximum relative humidity (Figure 7). For X. volvulus, the decision tree $\left(R^{2}=0.253\right.$; LogWorth $=2.4814 ; N=81$ ) contained mean solar radiation, maximum relative humidity, and minimum relative humidity as the first, second, and third split, respectively (Figure 8). Finally, the decision tree for X. bispinatus $\left(R^{2}=0.238\right.$; LogWorth $\left.=2.4907 ; N=81\right)$ revealed minimum solar radiation, maximum temperature, and minimum relative humidity as important variables influencing its abundance (Figure 9).

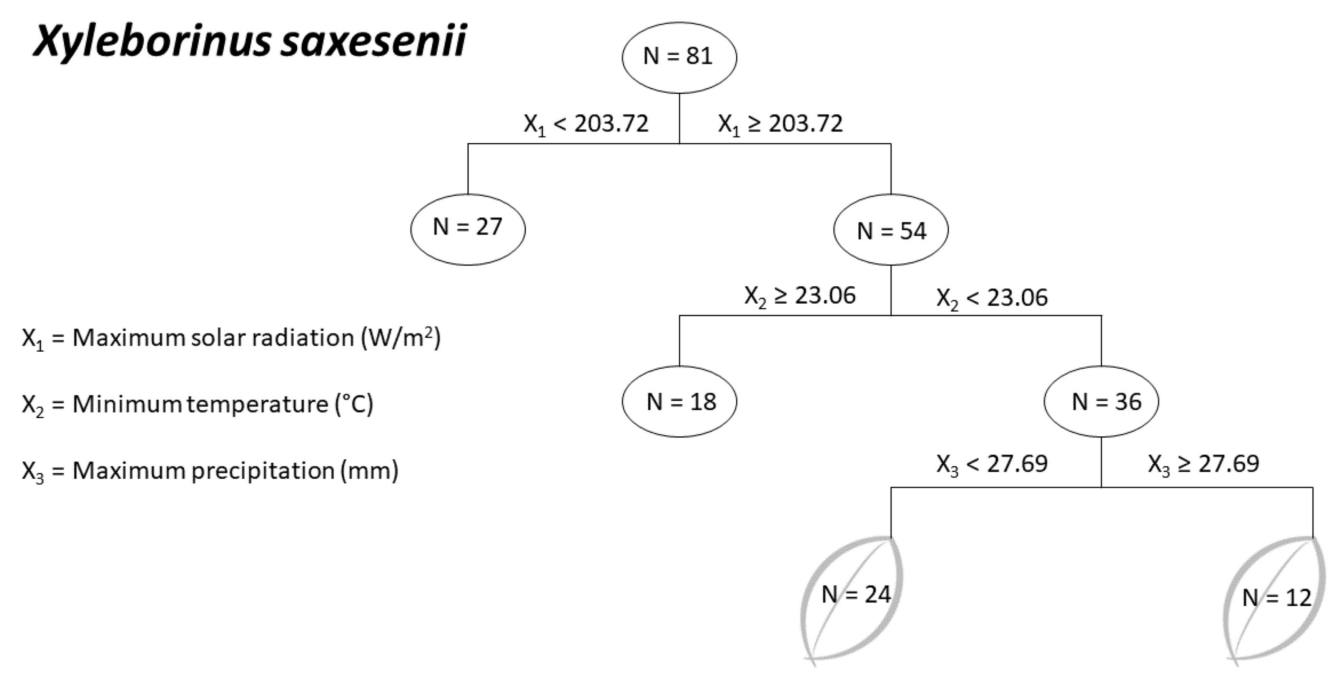

Figure 5. Decision tree schematic for Xyleborinus saxesenii abundance using weather conditions as explanatory variables.

\section{Xylosandrus crassiusculus}

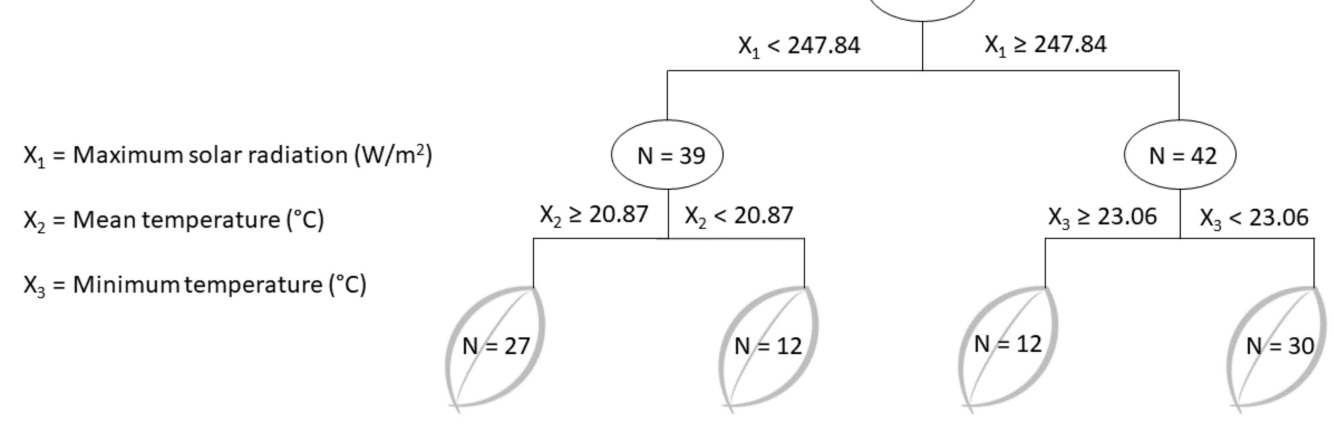

Figure 6. Decision tree schematic for Xylosandrus crassiusculus abundance using weather conditions as explanatory variables. 


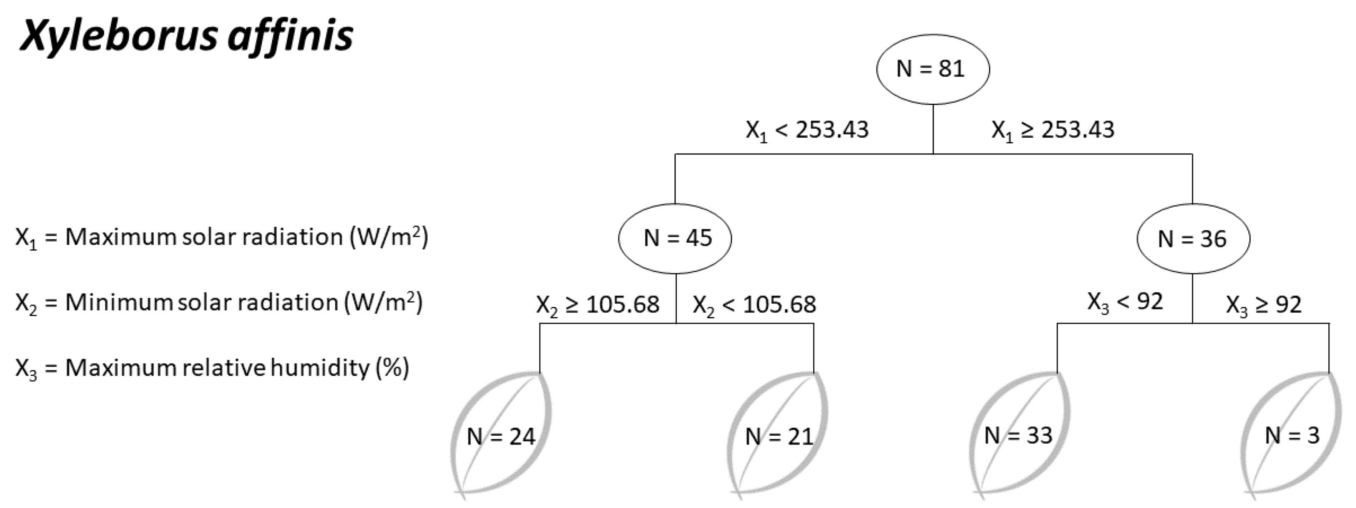

Figure 7. Decision tree schematic for Xyleborus affinis abundance using weather conditions as explanatory variables.

\section{Xyleborus volvulus}

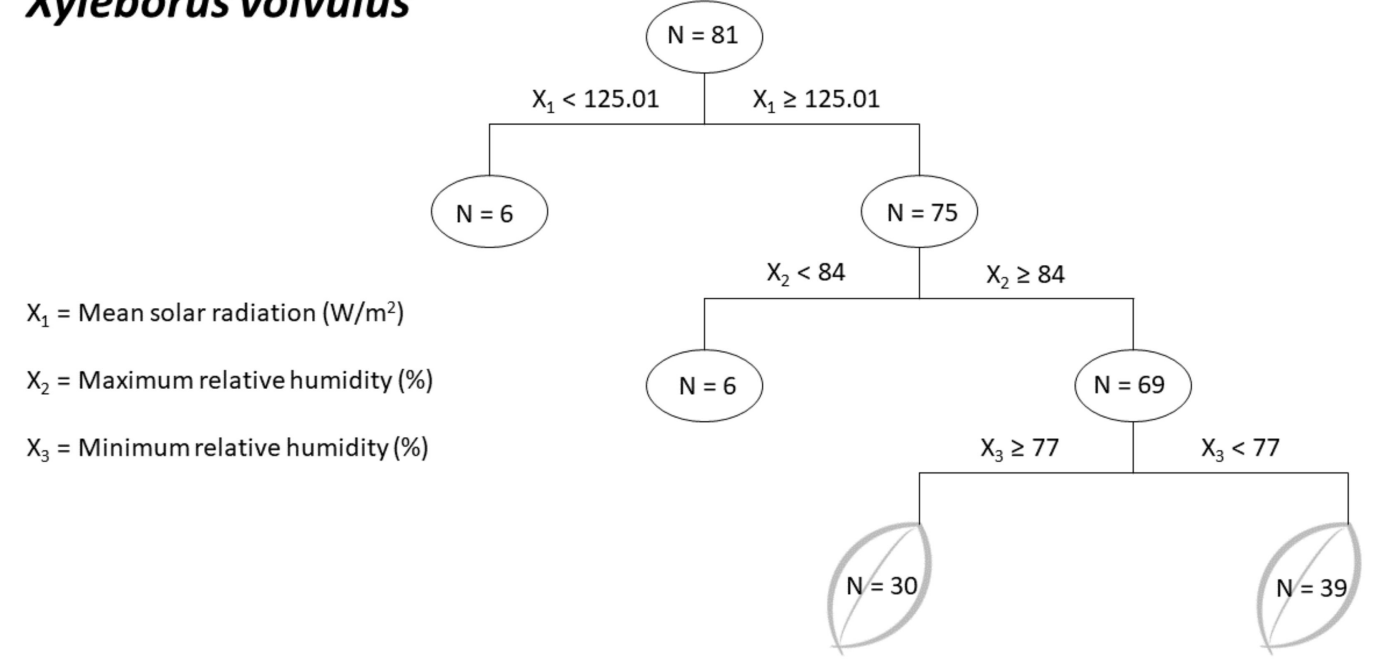

Figure 8. Decision tree schematic for Xyleborus volvulus abundance using weather conditions as explanatory variables.

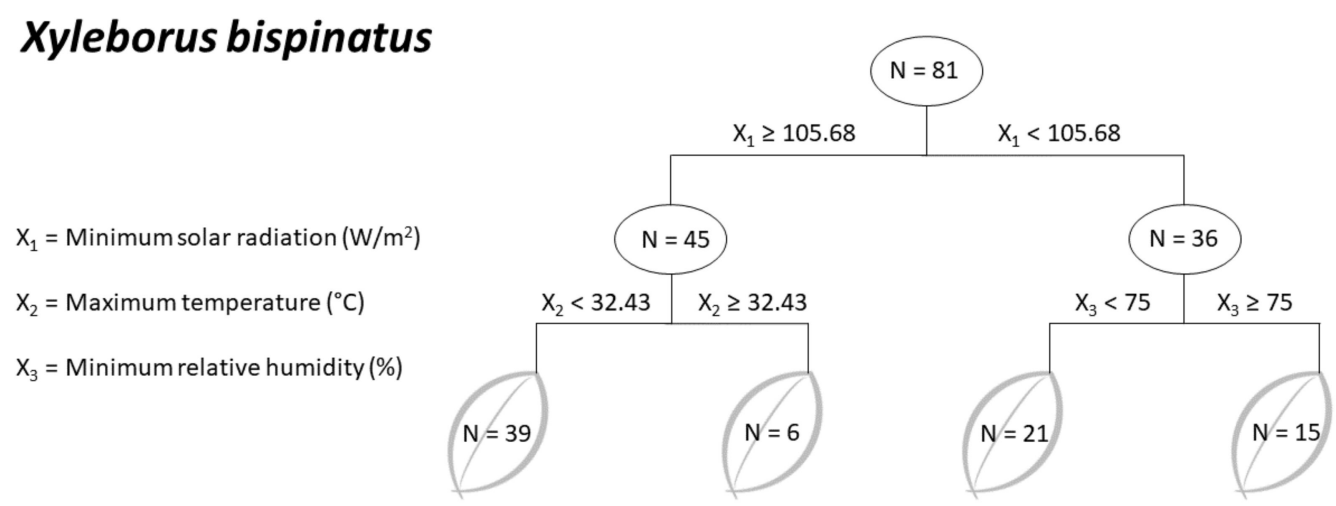

Figure 9. Decision tree schematic for Xyleborus bispinatus abundance using weather conditions as explanatory variables.

\section{Discussion}

Canopy management is a cultural practice extensively used to enhance productivity, maintain proper air flow, improve fruit set, optimize sunlight distribution, remove unhealthy sections of the trees, mitigate potential damage by hurricanes, and facilitate other cultural practices that help in the management of pests and diseases. In Florida, avocado 
growers prune and/or stump avocado trees-tree rejuvenation-to combat LW. Our results show that a reduction in canopy cover has a suppressive effect on some ambrosia beetle species, but most importantly on several species that vector the LW pathogen. Canopy management also alters the microclimatic conditions-especially light intensity - affecting ambrosia beetle abundance and flight activity. In addition, our results suggest that management in avocado orchards and meteorological factors play critical roles in determining the abundance and species composition of ambrosia beetle communities.

\subsection{Effect of Canopy Cover on Light Intensity Levels, Ambrosia Beetle Abundance, and Composition in LW-Affected Avocado Orchards}

All 15 beetle species were found beneath the three canopy covers in the three avocado orchards. Most species were more abundant in shaded areas (i.e., full canopy cover) as compared to sunny areas (i.e., topworked and new planting covers). We suggest that these results could be related to canopy openness. Dense canopies alter the microclimate below the canopy by decreasing the sunlight, temperature, and windspeed and increasing relative humidity [31-34]. These conditions are highly favorable for ambrosia beetles [18] and would promote an increase in population levels and the potential dispersal of females. Our results show that mature orchards with a dense canopy sustain higher numbers of ambrosia beetles. Interestingly, older orchards with dense canopies were the first to be impacted by LW when the epidemic started in 2012 and have been damaged more severely than younger orchards with more open canopies.

Thick canopy covers might act as a buffer zone that reduces light intensity within the orchard. The degree of light intensity resulting from canopy openness plays a significant role in insect activity [35,36]. Insects perceive an array of visual stimuli as they fly through the environment. In honeybees and bumblebees (Hymenoptera: Apidae), vision becomes less reliable when light intensity falls, resulting in a decline in their flight speed (i.e., flight becomes more challenging) [37,38]. However, other insects become more active near crepuscule and/or nightfall, especially those that occupy hidden, nocturnal, and subterranean (aphotic) habitats [39]. A negative relationship between light intensity and the number of Scolytinae captured in California and Florida was reported $[5,40]$. During daytime when high light intensity occurs, long-wavelength radiation governs the environment, but when the sun meets the horizon (i.e., twilight), light intensity decreases and the general luminosity changes rapidly to short wavelengths [41,42], allowing other insects to engage in flight [43]. Copious canopy covers may prolong the narrow time window when ambrosia beetles engage in flight. Additionally, ambrosia beetles could be active under specific wavelengths within the light spectrum; however, further studies of their phototaxis are needed to address this.

Another factor contributing to ambrosia beetle abundance and colonization is the diameter of the host trees. Trees with a large diameter, a common trait of mature trees with a dense canopy, were the first to be attacked by ambrosia beetles in redbay stands, whereas small trees with a smaller diameter remained healthy and unaffected $[44,45]$. We noticed a similar pattern at our study sites. The trunks of some topworked trees and trees with dense canopy had beetle entrance holes with tubes of extruded frass and chewed wood, evidence of active infestation; however, young small-diameter trees in new planting zones did not exhibit signs of ambrosia beetle attack. Xyleborus glabratus field experiments have shown that dispersing females rely on visual cues, including stem silhouette, as part of their host-seeking behavior $[46,47]$. Beetles may be more abundant under full canopy trees due to attraction to large trunk silhouettes, an adaptive behavior since large diameter trees are likely to support more progeny [44,48]. In addition, the kairomone attractants (i.e., terpenoid olfactory cues) used by ambrosia beetles for host location are found in highest concentrations in the trunk and large diameter branches $[49,50]$.

Like other small insects, ambrosia beetles may be influenced by microclimatic conditions. Open areas, such as new plantings in this study, have high light intensity, high temperature, high wind speed, and low humidity conditions [51]. Therefore, we presumed 
the ambrosia beetles may avoid these adverse conditions as their body temperature can increase rapidly when exposed to direct sunlight, which would intensify their metabolic rate (i.e., depleting nutrient reserves) and accelerate their water loss. All these conditions, consequences of exogenous factors, would strongly jeopardize their host-seeking behavior.

Our results suggest that in Florida avocado orchards, dense canopies can consequently promote/support ambrosia beetle abundance due to suitable microclimatic conditions. The effect of canopy openness on ambrosia beetle abundance and activity can be either transient or long-lasting, but this would likely depend on the periodicity of canopy management. Canopy management seems to help avocado growers battle against LW by suppressing beetle populations by reducing the time period of suitable conditions (i.e., low light, high $\mathrm{RH}$, and low wind speeds) for ambrosia beetle flight.

Although all ambrosia beetle species were documented in all orchards, some species were more abundant in orchard 1, whereas others were abundant in orchards 2 and 3. These results suggest that management history of avocado orchards has a significant repercussion on ambrosia beetle abundance. For instance, species not associated with the LW pathogen (i.e., A. lecontei, A. minor, E. perbrevis, P. cavipennis, T. ricini, X. andrewesi, $X$. gracilis, Hypothenemus spp., and E. parallelus) were very abundant in orchard 1 . This orchard was relatively young (ca. 15 years old) with active scouting and prompt removal of LW-symptomatic trees. Diligent scouting, pruning, and removal of infested trees would prevent ambrosia beetle population build-up and subsequent potential outbreaks. In contrast, orchards 2 and 3 were more than 50 years old, contained numerous standing LW-affected trees, and supported large numbers of $X$. crassiusculus, X. affinis, X. volvulus, $X$. bispinatus, and $X$. saxesenii, which have a high probability of carrying $R$. lauricola [9-11]. The combined results of this study and previously published reports [2-4] indicate that these five species thrive in South Florida avocado orchards. The low light intensity from dense canopies and the large surplus of breeding material (i.e., stressed trees) would facilitate population increases in older avocado orchards. In addition, these polyphagous species are found in several natural and disturbed areas in South Florida [16,52,53], which can function as reservoirs for beetles that can immigrate into avocado orchards.

\subsection{Effect of Meteorological Factors on Ambrosia Beetle Flight Activity}

Solar radiation (i.e., sunlight) was the most significant factor influencing the flight activity of the five LW vectors in the avocado orchards. In South Florida, high solar radiation $\left(>200 \mathrm{~W} / \mathrm{m}^{2}\right)$ commonly occurs during the spring and decreases continuously until the winter (FAWN-https: / / fawn.ifas.ufl.edu/ accessed on 28 May 2020). Temperature $\left(\sim 23{ }^{\circ} \mathrm{C}\right)$ was the second most influential factor for X. saxesenii and X. crassiusculus. Temperature is typically high at the end of the spring and early summer, declining up to ca. $15{ }^{\circ} \mathrm{C}$ in the winter months. Both conditions generally co-occurred between March and late July, resulting in the most favorable conditions for X. saxesenii and X. crassiusculus flight (Figures S1 and S2). Our results support previous investigations conducted in avocado orchards that reported high captures of these species during this period [4,5]. These two species are invasive in the continental USA, and they have been documented to be highly active between April and May in Illinois (IL), Kentucky (KY), Missouri (MO), North Carolina (NC), Ohio (OH), Tennessee (TN), and Virginia (VA) [54-59], whereas our data show flight peaks between March and late July in southern Florida (Figures S1 and S5). The former states have a more temperate climate, whereas south Florida exhibits a subtropical climate with warmer temperatures and higher humidity. These results suggest that the flight activity of $X$. crassiusculus and X. saxesenii differs geographically, with peak dispersal periods determined by the climatic conditions of the area investigated.

In addition to solar radiation and temperature, the activity of $X$. affinis, $X$. volvulus, and $X$. bispinatus was also influenced by relative humidity. The $R^{2}$ values obtained for these species from the decision tree analyses were relatively low compared to those of $X$. saxesenii and X. crassiusculus, suggesting that meteorological factors only partially explain their flight activity in South Florida avocado orchards. Xyleborus affinis and X. bispinatus 
displayed two similar flight peaks: the first from April to late June and the second between November and December (Figures S2 and S4). Solar radiation and temperature were high during the first dispersal peak; however, there was less solar radiation and the temperature was slightly cooler during the second peak. In contrast, X. volvulus displayed a more unpredictable flight pattern throughout the year (Figure S3). Xyleborus affinis, X. volvulus, and $X$. bispinatus may be well adapted to the variable conditions of Florida weather. This suggests that their abundance and activity are affected mainly by cultural practices within each avocado orchard and that meteorological factors play a secondary role. It is worth mentioning that these five species decreased their flight activities during the rainy season (data not shown), probably because precipitation hampers the flight of these small beetles by inflicting pressure on their bodies and wings.

Several studies have investigated the effect of environmental conditions on the flight activity of several scolytine species; however, they have yielded conflicting results [21-23,40,60-66]. High bark beetle activity was reported in areas with high solar radiation [22], but other studies reported the opposite [51]. A different study documented that high relative humidity and low temperatures were the most favorable conditions for seasonal flight patterns of ambrosia beetles in agricultural settings in southern Thailand [63]. However, flight activity of $P$. juglandis was correlated negatively with relative humidity [23]. The discrepancy of these results implies that bark and ambrosia beetles require species-specific climatic conditions to engage in host-seeking flight.

\section{Conclusions}

The current study indicates that canopy covers affect the abundance of ambrosia beetles by modifying the levels of light intensity within avocado orchards. Dense canopy covers sustain larger beetle populations, especially of species implicated in LW transmission. Pruning and other cultural practices that reduce canopy densities also suppress ambrosia beetle activity. Meteorological conditions were significant explanatory variables for the flight activities of $X$. crassiusculus and $X$. saxesenii, but not for the flight activity of $X$. volvulus, $X$. affinis, and X. bispinatus. This implies that invasive species are more sensitive to weather conditions, but other factors might be of more relevance for resident species. Overall, our results suggest that the abundance and species composition of bark and ambrosia beetles in avocado orchards are determined by the interaction of multiple factors, including orchard management history, meteorological factors, age (i.e., tree size) and physiological state of trees (i.e., stress), and the biology of the beetles. From a broader perspective, our results imply that the most effective management strategy is to prevent ambrosia beetle attacks in the first place by reducing conditions favorable for ambrosia beetles within the orchard. Canopy management along with phytosanitary measures (i.e., removal of symptomatic trees) already practiced by avocado growers, may greatly reduce the incidence of $\mathrm{LW}$ within their orchards. Finally, these results show areas and conditions within an orchard favorable for ambrosia beetles. This indicates what areas avocado growers should prioritize for early detection of alternative vectors of $R$. lauricola.

Supplementary Materials: The following supporting information can be downloaded from https: / / www.mdpi.com/article/10.3390/agronomy12030547/s1. Figure S1: Seasonal flight pattern of $X$. crassiusculus in three commercial avocado orchards (top row) and maximum solar radiation (bottom row) over a one-year period. The dashed line indicates the critical value for the first split obtained from the decision tree analysis. Figure S2: Seasonal flight pattern of X. affinis in three commercial avocado orchards (top row) and maximum solar radiation (bottom row) over a one-year period. The dashed line indicates the critical value for the first split obtained from the decision tree analysis. Figure S3: Seasonal flight pattern of X. volvulus in three commercial avocado orchards (top row) and mean solar radiation (bottom row) over a one-year period. The dashed line indicates the critical value for the first split obtained from the decision tree analysis. Figure S4: Seasonal flight pattern of X. bispinatus in three commercial avocado orchards (top row) and minimum solar radiation (bottom row) over a one-year period. The dashed line indicates the critical value for the first split obtained from the decision tree analysis. Figure S5: Seasonal flight pattern of X. saxesenii in three commercial 
avocado orchards (top row) and maximum solar radiation (bottom row) over a one-year period. The dashed line indicates the critical value for the first split obtained from the decision tree analysis.

Author Contributions: Conceptualization: O.M., J.H.C. and D.C.; methodology: O.M., J.H.C. and D.C.; data collection: O.M., A.P., P.C.C. and E.A.C.; data curation: O.M., A.P., P.C.C. and E.A.C.; visualization: O.M.; data analysis: O.M.; writing—original draft preparation: O.M.; supervision: D.C.; resources: P.E.K. and J.H.C.; feedback and comments on previous versions of the manuscript: P.E.K., J.H.C. and D.C.; final review and editing: P.E.K. and D.C.; funding acquisition: D.C. All authors have read and agreed to the published version of the manuscript.

Funding: This research was funded by a NIFA grant 2015-51181-24257 awarded to Daniel Carrillo and by a Non-Assistance Cooperative Agreement between the USDA-ARS and the University of Florida (Number: 58-6038-8-004).

Data Availability Statement: Data are contained within the article.

Acknowledgments: The authors are grateful to José Alegría and Rita E. Duncan for their technical assistance during data collection and sample sorting. We thank James Colee (UF/IFAS—Statistical Consulting Unit) for his valuable help during the statistical analysis. We thank CAPES and CNPq for P.C.C and E.A.C scholarships. We would also like to thank the avocado orchard owners for granting permission to conduct research in their orchards.

Conflicts of Interest: The authors declare no conflict of interest. The mention of a trademark or proprietary product does not constitute a guarantee or warranty of the product by the USDA-ARS and does not imply its approval to the exclusion of other products that may also be suitable. USDA is an equal opportunity provider and employer. The funders had no role in the design of the study; in the collection, analyses, or interpretation of data; in the writing of the manuscript, or in the decision to publish the results.

\section{References}

1. Food and Agriculture Organization of the United Nations (FAO). FAOSTAT_Countries by Commodity. Available online: https:/ / www.fao.org/faostat/en/\#rankings/countries_by_commodity. (accessed on 25 November 2021).

2. Carrillo, D.; Duncan, R.E.; Peña, J.E. Ambrosia beetles (Coleoptera: Curculionidae: Scolytinae) that breed in avocado wood in Florida. Fla. Entomol. 2012, 95, 573-579. [CrossRef]

3. Kendra, P.E.; Owens, D.; Montgomery, W.S.; Narvaez, T.I.; Bauchan, G.R.; Schnell, E.Q.; Tabanca, N.; Carrillo, D. $\alpha$-Copaene is an attractant, synergistic with quercivorol, for improved detection of Euwallacea nr. fornicatus (Coleoptera: Curculionidae: Scolytinae). PLoS ONE 2017, 12, e0179416. [CrossRef] [PubMed]

4. Kendra, P.E.; Montgomery, W.S.; Narvaez, T.I.; Carrillo, D. Comparison of trap designs for detection of Euwallacea nr. fornicatus and other Scolytinae (Coleoptera: Curculionidae) that vector fungal pathogens of avocado trees in Florida. J. Econ. Entomol. 2020, 113, 980-987. [PubMed]

5. Menocal, O.; Kendra, P.E.; Montgomery, W.S.; Crane, J.H.; Carrillo, D. Vertical distribution and daily flight periodicity of ambrosia beetles (Coleoptera: Curculionidae) in Florida avocado orchards affected by laurel wilt. J. Econ. Entomol. 2018, 111, 1190-1196. [CrossRef]

6. $\quad$ Owens, D.; Kendra, P.E.; Tabanca, N.; Narvaez, T.I.; Montgomery, W.S.; Schnell, E.Q.; Carrillo, D. Quantitative analysis of contents and volatile emissions from $\alpha$-copaene and quercivorol lures, and longevity for attraction of Euwallacea nr. fornicatus in Florida. J. Pest. Sci. 2019, 92, 237-252. [CrossRef]

7. Owens, D.; Seo, M.; Montgomery, W.S.; Rivera, M.J.; Stelinski, L.L.; Kendra, P.E. Dispersal behavior of Euwallacea nr. fornicatus (Coleoptera: Curculionidae: Scolytinae) in avocado groves and estimation of lure sampling range. Agric. For. Entomol. 2019, 21, 199-208. [CrossRef]

8. Rivera, M.J.; Martini, X.; Conover, D.; Mafra-Neto, A.; Carrillo, D.; Stelinski, L.L. Evaluation of semiochemical based push-pull strategy for population suppression off ambrosia beetle vectors of laurel wilt disease in avocado. Sci. Rep. 2020, 10, 2670. [CrossRef]

9. Carrillo, D.; Duncan, R.E.; Ploetz, J.N.; Campbell, A.F.; Ploetz, R.C.; Peña, P.E. Lateral transfer of a phytopathogenic symbiont among native and exotic ambrosia beetles. Plant. Pathol. 2014, 63, 54-62. [CrossRef]

10. Ploetz, R.C.; Konkol, J.L.; Narvaez, T.; Duncan, R.E.; Saucedo, R.J.; Campbell, A.; Mantilla, J.; Carrillo, D.; Kendra, P.E. Presence and prevalence of Raffaelea lauricola, cause of laurel wilt, in different species of ambrosia beetle in Florida, USA. J. Econ. Entomol. 2017, 110, 347-354.

11. Saucedo-Carabez, J.R.; Ploetz, R.C.; Konkol, J.L.; Carrillo, D.; Gazis, R. Partnerships between ambrosia beetles and fungi: Lineage-specific promiscuity among vectors of the laurel wilt pathogen, Raffaelea lauricola. Microb. Ecol. 2018, 76, 925-940. [CrossRef] 
12. Basset, Y.; Charles, E.; Hammond, D.S.; Brown, V.K. Short-term effects of canopy openness on insect herbivores in a rain forest in Guyana. J. Appl. Ecol. 2001, 38, 1045-1058. [CrossRef]

13. Rahman, M.A.; Moser, A.; Gold, A.; Rotzer, T.; Pauleit, S. Vertical air temperature gradients under the shade of two contrasting urban tree species during different types of summer days. Sci. Total Environ. 2018, 633, 100-111. [CrossRef] [PubMed]

14. Brar, G.S.; Capinera, J.L.; McLean, S.; Kendra, P.E.; Ploetz, R.C.; Peña, P.E. Effect of trap size, trap height, and age of lure on sampling Xyleborus glabratus (Coleoptera: Curculionidae: Scolytinae), and its flight periodicity and seasonality. Fla. Entomol. 2012, 95, 1003-1011. [CrossRef]

15. Kendra, P.E.; Montgomery, W.S.; Niogret, J.; Deyrup, M.A.; Guillén, L.; Epsky, N.D. Xyleborus glabratus, X. affinis, and X. ferrugineus (Coleoptera: Curculionidae: Scolytinae): Electroantennogram responses to host-based attractants and temporal patterns in host-seeking flight. Environ. Entomol. 2012, 41, 1597-1605. [CrossRef] [PubMed]

16. Kendra, P.E.; Montgomery, W.S.; Sanchez, J.S.; Deyrup, M.A.; Niogret, J.; Epsky, N.D. Method for collection of live redbay ambrosia beetles, Xyleborus glabratus (Coleoptera: Curculionidae: Scolytinae). Fla. Entomol. 2012, 95, 513-516. [CrossRef]

17. Johnson, A.J.; Kendra, P.E.; Skelton, J.; Hulcr, J. Species diversity, phenology, and temporal flight patterns of Hypothenemus pygmy borers (Coleoptera: Curculionidae: Scolytinae) in south Florida. Environ. Entomol. 2016, 45, 627-632. [CrossRef] [PubMed]

18. Rudinsky, J.A. Ecology of Scolytidae. Annu. Rev. Entomol. 1962, 7, 327-348. [CrossRef]

19. Covre, L.de.S.; Melo, A.A.; Flechtmann, C.A.H. Flight activity and spread of Xylosandrus crassiusculus (Motschulsky) (Coleoptera: Curculionidae) in Brazil. Trees For. People. 2021, 4, 100076. [CrossRef]

20. Martínez, M.; Cognato, A.I.; Guachambala, M.; Boivin, T. Bark and ambrosia beetle (Coleoptera: Curculionidae: Scolytinae) diversity in natural and plantation forests in Ecuador. Environ. Entomol. 2019, 48, 603-613. [CrossRef]

21. Mezei, P.; Jakuš, R.; Blaženec, M.; Belánová, S.; Šmídt, J. The relationship between potential solar radiation and spruce bark beetle catches in pheromone traps. Ann. For. Res. 2012, 55, 243-252.

22. Mezei, P.; Potterf, M.; Škvarenina, J.; Rasmussen, J.G.; Jakuš, R. Potential solar radiation as a driver for bark beetle infestation on a landscape scale. Forests 2019, 10, 604. [CrossRef]

23. Chen, Y.; Aukema, B.H.; Seybold, S.J. The effects of weather on the flight of an invasive bark beetle, Pityophthorus juglandis. Insects 2020, 11, 156. [CrossRef] [PubMed]

24. Rabaglia, R.J.; Dole, S.A.; Cognato, A.I. Review of American Xyleborina (Coleoptera: Curculionidae: Scolytinae) occurring North of Mexico, with an illustrated key. Ann. Entomol. Soc. Am. 2006, 99, 1034-1056. [CrossRef]

25. Atkinson, T.H.; Carrillo, D.; Duncan, R.E.; Peña, J.E. Occurrence of Xyleborus bispinatus (Coleoptera: Curculionidae: Scolytinae) Eichhoff in southern Florida. Zootaxa 2013, 3669, 96-100. [CrossRef]

26. Gomez, D.F.; Rabaglia, R.J.; Fairbanks, K.E.O.; Hulcr, J. North American Xyleborini north of Mexico: A review and key to genera and species (Coleoptera, Curculionidae, Scolytinae). ZooKeys 2018, 768, 19-68. [CrossRef]

27. De'ath, G.; Fabricius, K.E. Classification and regression trees: A powerful yet simple technique for ecological data analysis. Ecology 2000, 81, 3178-3192. [CrossRef]

28. De'ath, G. Multivariate regression trees: A new technique for modeling species-environment relationships. Ecology 2002, 83, 1105-1117.

29. Wray, B.A.; Jones, A.T.; Schuhmann, P.W.; Burrus, R.T. Determining the propensity for academic dishonesty using decision tree analysis. Ethics. Behav. 2016, 26, 470-487. [CrossRef]

30. Shaikhina, T.; Lowe, D.; Daga, S.; Briggs, D.; Higgins, R.; Khovanova, N. Decision tree and random forest models for outcome prediction in antibody incompatible kidney transplantation. Biomed. Signal. Proces. 2019, 52, 456-462. [CrossRef]

31. Messier, C.; Parent, S.; Bergeron, Y. Effects of overstory and understory vegetation on the understory light environment in mixed boreal forest. J. Veg. Sci. 1998, 9, 511-520. [CrossRef]

32. Aussenac, G. Interaction between forest stands and microclimatic: Ecophysiological aspects and consequences for silviculture. Ann. For. Sci. 2000, 57, 287-301. [CrossRef]

33. Lebrija-Trejos, E.; Pérez-García, E.A.; Meave, J.A.; Poorter, L.; Bongers, F. Environmental changes during secondary succession in a tropical dry forest in Mexico. J. Trop. Ecol. 2011, 27, 477-489. [CrossRef]

34. Inskeep, J.R.; Allen, A.P.; Taylor, P.W.; Rempoulakis, P.; Weldon, C.W. Canopy distribution and microclimate preferences of sterile and wild Queensland fruit flies. Sci. Rep. 2021, 11, 13010. [CrossRef]

35. Sane, S.P. The aerodynamics of insect flight. J. Exp. Biol. 2003, 206, 4191-4208. [CrossRef] [PubMed]

36. Baird, E.; Srinivasan, M.V.; Zhang, S.; Cowling, A. Visual control of flight speed in honeybees. J. Exp. Biol. 2005, 208, 3895-3905. [CrossRef]

37. Burrill, R.M.; Dietz, A. The response of honeybees to variations in solar radiation and temperature. Apidologie 1981, 12, 318-329. [CrossRef]

38. Reber, T.; Vahakainu, A.; Baird, E.; Weckstrom, M.; Warrant, E.; Dacke, M. Effect of light intensity on flight control and temporal properties of photoreceptors in bumblebees. J. Exp. Biol. 2015, 218, 1339-1346. [CrossRef] [PubMed]

39. Owens, A.C.S.; Lewis, S.M. The impact of artificial light at night on nocturnal insects: A review and synthesis. Ecol. Evol. 2018, 8, 11337-11358. [CrossRef]

40. Chen, Y.; Seybold, S.J. Crepuscular flight activity of an invasive insect governed by interacting abiotic factors. PLoS ONE 2014, 9, e105945. [CrossRef] 
41. Bernáth, B.; Gál, J.; Horváth, G. Why is it worth flying at dusk for aquatic insects? Polarotactic water detection is easiest at low solar elevations. J. Exp. Biol. 2004, 207, 755-765. [CrossRef]

42. Narendra, A.; Reid, S.F.; Hemmi, J.M. The twilight zone: Ambient light levels trigger activity in primitive ants. Proc. R. Soc. B. 2010, 277, 1531-1538. [CrossRef] [PubMed]

43. Reynolds, A.M.; Reynolds, D.R.; Smith, A.D.; Chapman, J.W. Orientation cues for high-flying nocturnal insect migrants: Do turbulence-induced temperature and velocity fluctuations indicate the mean wind flow? PLoS ONE 2010, 5, e15758. [CrossRef] [PubMed]

44. Fraedrich, S.W.; Harrington, T.C.; Rabaglia, R.J.; Ulyshen, M.D.; Mayfield III, A.E.; Hanula, J.L.; Eickwort, J.M.; Miller, D.R. A fungal symbiont of redbay ambrosia beetle causes a lethal wilt in redbay and other Lauraceae in the southern United States. Plant. Dis. 2008, 92, 215-224. [CrossRef] [PubMed]

45. Shields, J.; Jose, S.; Freeman, J.; Bunyan, M.; Celis, G.; Hagan, D.; Morgan, M.; Pieterson, E.C.; Zak, J. Short-term impacts of laurel wilt on redbay (Persea borbonia [L.] Spreng.) in a mixed evergreen-deciduous forest in Northern Florida. J. For. 2011, $109,82-88$.

46. Mayfield, A.E., III; Brownie, C. The redbay ambrosia beetle (Coleoptera: Curculionidae: Scolytinae) uses stem silhouette diameter as a visual host-finding cue. Environ. Entomol. 2013, 42, 743-750. [CrossRef] [PubMed]

47. Maner, M.L.; Hanula, J.L.; Horn, S. Population trends of the redbay ambrosia beetle (Coleoptera: Curculionidae: Scolytinae): Does utilization of small diameter redbay trees allow populations to persist? Fla. Entomol. 2014, 97, 208-216. [CrossRef]

48. Ulyshen, M.D.; Sheehan, T.N. Trap height considerations for detecting two economically important forest beetle guilds in southeastern US forests. J. Pest. Sci. 2019, 92, 253-265. [CrossRef]

49. Niogret, J.; Epsky, N.D.; Schnell, R.J.; Boza, E.J.; Kendra, P.E.; Heath, R.R. Terpenoid variations within and among half-sibling avocado trees, Persea americana Mill. (Lauraceae). PLoS ONE 2013, 8, e73601. [CrossRef]

50. Kendra, P.E.; Montgomery, W.S.; Niogret, J.; Pruett, G.E.; Mayfield, A.E., III; MacKenzie, M.; Deyrup, M.A.; Bauchan, G.R.; Ploetz, R.C.; Epsky, N.D. North American Lauraceae: Terpenoid emissions, relative attraction and boring preferences of redbay ambrosia beetle, Xyleborus glabratus (Coleoptera: Curculionidae: Scolytinae). PLoS ONE 2014, 9, e102086. [CrossRef]

51. Rodríguez, C.S.; Cognato, A.I.; Righi, C.A. Bark and ambrosia beetle (Curculionidae: Scolytinae) diversity found in agricultural and fragmented forests in Piracicaba-SP, Brazil. Environ. Entomol. 2017, 46, 1254-1263. [CrossRef]

52. Kendra, P.E.; Montgomery, W.S.; Schnell, E.Q.; Deyrup, M.A.; Epsky, N.D. Efficacy of $\alpha$-copaene, cubeb, and eucalyptol lures for detection of redbay ambrosia beetle (Coleoptera: Curculionidae: Scolytinae). J. Econ. Entomol. 2016, 109, 2428-2435. [CrossRef] [PubMed]

53. Wheeler, G.S.; Kendra, P.E.; David, A.S.; Lake, E.C.; Sigmon, J.W.; Palacios, J.; Donlan, E.M. Community of bark and ambrosia beetles (Coleoptera: Curculionidae: Scolytinae and Platypodinae) infesting Brazilian peppertree treated with herbicide and the volatile tree response. Environ. Entomol. 2021, 50, 1311-1321. [CrossRef] [PubMed]

54. Roling, M.P.; Kearby, W.H. Seasonal flight and vertical distribution of Scolytidae attracted to ethanol in an oak-hickory forest in Missouri. Can. Ent. 1975, 107, 1315-1320. [CrossRef]

55. Weber, B.C.; McPherson, J.E. Seasonal flight patterns of Scolytidae (Coleoptera) in black walnut plantations in North Carolina and Illinois. Coleopt. Bull. 1991, 45, 45-56.

56. Oliver, J.B.; Mannion, C.M. Ambrosia beetle (Coleoptera: Scolytidae) species attacking chestnut and captured in ethanol-baited traps in middle Tennessee. Environ. Entomol. 2001, 30, 909-918. [CrossRef]

57. Reding, M.; Oliver, J.; Schultz, P.; Ranger, C. Monitoring flight activity of ambrosia beetles in ornamental nurseries with ethanol-baited traps: Influence of trap height on captures. J. Environ. Hort. 2010, 28, 85-90. [CrossRef]

58. Reding, M.E.; Schultz, P.B.; Ranger, C.M.; Oliver, J.B. Optimizing ethanol-baited traps for monitoring damaging ambrosia beetles (Coleoptera: Curculionidae, Scolytinae) in ornamental nurseries. J. Econ. Entomol. 2011, 104, 2017-2024. [CrossRef]

59. Viloria, Z.; Villanueva, R.T.; Bessin, R.; O’Neal, P.; Ranger, C.M.; Dunwell, W. Scolytinae in nursery and fruit crops of western Kentucky and seasonal population patterns of four invasive ambrosia beetles. J. Entomol. Sci. 2021, 56, 374-386. [CrossRef]

60. Wermelinger, B.; Seifert, M. Analysis of temperature dependent development of the spruce bark beetle Ips typographus. (L.) (Col., Scolytidae). J. Appl. Entomol. 1998, 122, 185-191. [CrossRef]

61. Aukema, B.H.; Clayton, M.K.; Raffa, K.F. Modeling flight activity and population dynamics of the pine engraver, Ips pini, in the Great Lakes region: Effects of weather and predators over short time scales. Popul. Ecol. 2005, 47, 61-69. [CrossRef]

62. Gaylord, M.L.; Williams, K.K.; Hofstetter, R.W.; McMillin, J.D.; DeGomez, T.E.; Wagner, M.R. Influence of temperature on spring flight initiation for southwestern ponderosa pine bark beetles (Coleoptera: Curculionidae, Scolytinae). Environ. Entomol. 2008, 37, 57-69. [CrossRef]

63. Sittichaya, W.; Permkam, S.; Cognato, A.I. Species composition and flight pattern of Xyleborini ambrosia beetles (Col.: Curculionidae: Scolytinae) from agricultural areas in southern Thailand. Environ. Entomol. 2012, 41, 776-784. [CrossRef]

64. Kautz, M.; Schopf, R.; Osher, J. The "Sun-effect": Microclimatic alterations predispose forest edges to bark beetle infestations. Eur. J. For. Res. 2013, 132, 453-465. [CrossRef]

65. Marini, L.; Økland, B.; Jönsson, A.M.; Bentz, B.; Carroll, A.; Forster, B.; Gregoire, J.-C.; Hurling, R.; Nageleisen, L.M.; Netherer, S.; et al. Climate drivers of bark beetle outbreak dynamics in Norway spruce forests. Ecography 2017, 40, 1426-1435. [CrossRef]

66. Gomez, D.F.; Skelton, J.; María, M.de.; Hulcr, J. Influence of temperature and precipitation anomaly on the seasonal emergence of invasive bark beetles in subtropical South America. Neotrop. Entomol. 2020, 49, 347-352. [CrossRef] 